\title{
Initial care for burned patients in academic nursing education*
}

\author{
Atendimento inicial ao queimado na formação acadêmica de enfermagem
}

William Campo Meschial ${ }^{1}$, Magda Lúcia Félix de Oliveira ${ }^{1}$

Objective: to describe the experience of Nursing students in the initial care for burned patients. Methods: a cross-sectional study was carried out with 107 Nursing students from four Higher Education Institutions. A modular structured questionnaire divided in three blocks was used. Data were analyzed through descriptive statistics in the Epi Info ${ }^{\circledR} 6.04$ software. Results: the majority (94.4\%) of students reported that initial care for burned patients was addressed in undergraduate courses, but $81.6 \%$ considered the approach insufficient. Regarding the theory-practice relationship, $47.7 \%$ reported having participated in extracurricular theoretical activities, and $28.0 \%$ had performed practical activities of initial care for burned patients. All students considered it important to approach this theme during undergraduate training; $38.7 \%$ said this was extremely important, but $41.1 \%$ had little or no affinity with the subject. Conclusion: the experience in this theme, especially in practical activities, was considered insufficient by Nursing students, indicating the urgent need to rethink teaching practices.

Descriptors: Burns; Emergency Nursing; Studentes, Nursing.

Objetivo: descrever a vivência de estudantes de Enfermagem no atendimento inicial ao queimado. Métodos: estudo transversal, realizado com 107 estudantes de Enfermagem de quatro Instituições de Educação Superior. Utilizou-se um questionário modular, estruturado, dividido em três blocos. Os dados foram analisados por meio de estatística descritiva, por meio do programa Epi Info ${ }^{\circledR}$ 6.04. Resultados: a maioria $(94,4 \%)$ informou que o atendimento inicial ao queimado foi abordado em disciplinas da graduação, porém $81,6 \%$ consideraram a abordagem insuficiente. Sobre a relação teoria-prática da abordagem, 47,7\% afirmaram ter participado de atividades teóricas extracurriculares, e 28,0\% realizaram atividades práticas do atendimento inicial ao queimado. A totalidade dos alunos considerou importante a abordagem desse tema na graduação: $38,7 \%$ afirmaram ser extremamente importante, mas $41,1 \%$ possuíam pouca ou nenhuma afinidade com o tema. Conclusão: a vivência do tema, em especial nas atividades práticas, foi considerada insuficiente pelos estudantes de Enfermagem, indicando a necessidade premente de repensar práticas de ensino.

Descritores: Queimaduras; Enfermagem em Emergência; Estudantes de Enfermagem.

\footnotetext{
*Excerpt from the dissertation "Atendimento inicial ao queimado em unidades de urgência: conhecimento teórico de estudantes de enfermagem", Universidade Estadual de Maringá, 2012.

${ }^{1}$ Universidade Estadual de Maringá. Maringá, PR, Brazil.

Corresponding author: Wiliam Campo Meschial

Avenida Colombo, 5.790 - Campus Universitário - Bloco 002, sala 001, CEP: 87020-900. Maringá, PR, Brazil. E-mail: williameschial@yahoo. com.br
} 


\section{Introduction}

The responsibility of training skilled nurses to the reality of clinical practice, with a view to ensuring patient safety and excellence of Nursing practice, is shared between national and international Nursing councils and Higher Education Institutions ${ }^{(1)}$. In Brazil, National Curricular Guidelines have aimed at the training of nurses with skills and abilities to know and intervene in emerging health-disease problems and situations with epidemiological impact, with emphasis on the region in which they are inserted. In this sense, burn accidents stand out; they are relevant morbidity and mortality causes in the country.

The global incidence of burn victims receiving health care is approximately 11 million people, and burns and fires are responsible for more than 300,000 deaths worldwide. Furthermore, most non-fatal accidents tend to lead to disabilities, especially in developing countries, such as Brazil, where the population has mostly low and middle income, prevention programs are few, and the quality of initial care is precarious $^{(2-3)}$.

Proper management of initial medical and nursing care is crucial for burn patients, to restrain the progression of burns and, consequently, the associated sequelae. However, knowledge of the principles governing care in this area is universally poor, especially among health workers in emergency units ${ }^{(4)}$.

A study carried out in England with the objective of evaluating undergraduate students' knowledge on first care measures to burn patients showed that they lack theoretical and practical knowledge ${ }^{(5)}$. In Brazil, few investigations to date have evaluated the knowledge and training of nursing professionals to provide care for burn victims ${ }^{(6)}$.

Nursing education on initial care for burn accidents must be addressed during undergraduate training so as to enable nurses to perform qualified care. Thus, studies investigating the approach of themes that represent important public health problems such as burn injuries are fundamental to identify possible gaps in the teaching-learning process. They also contribute to subsidize educational interventions or even curricular changes in vocational training, aiming at a better preparation in this area.

In this sense, the present study aimed to describe the nursing students experience in the provision of initial care for burned patients.

\section{Methods}

This research is a cross-sectional descriptive study carried out with undergraduate nursing students from the metropolitan region of Maringá, Brazil, northwest of the state, which currently has 26 municipalities and a population of more than 700 thousand inhabitants. Three municipalities offer undergraduate Nursing courses: Maringá, Ivatuba and Mandaguari, which have a population of 357,117, 3,008 and 32,658 inhabitants, respectively.

The inclusion criteria used for selecting Higher Education Institutions were: offer of Nursing Course in the face-to-face modality and having classes attending the last semester of the course. Five institutions met the pre-established criteria; however, data collection could not be carried out in one of them because the academic had ended.

Three out of the four higher education institutions selected are located in Maringá and one in Ivatuba. Of these, one institution is public and the others, private. They have together a total of 136 students enrolled in the last semester of undergraduate nursing courses. It is worth mentioning that the curricular apprenticeship of Ivatuba Nursing course is held in Maringá due to the lack of field for practice in that municipality. The inclusion criterion for students was to be regularly enrolled in the last semester of the Nursing course in one of the study institutions in the academic year of 2012 - regardless of the number of courses they were attending at that semester.

A list with the names of the students enrolled in each institution, by series and course, and also a spreadsheet with shift and schedule of classes, pro- 
vided by the Academic Secretary, were used for selection of students.

From 136 nursing students that met the inclusion criteria, 107 (79.3\%) responded to the data collection instrument. A total of 29 losses occurred due to refusal to complete the research instrument (3 - 10.3\%), no show at the moment of data collection (25-86.2\%) and devolution of unfilled instrument (1 $-3.5 \%)$.

A modular, structured and self-applied research instrument with multiple choice questions was used. The instrument was divided into three blocks: Block I: Sociodemographic, socioeconomic characterization $^{(7)}$, with 10 questions for student characterization; Block II: Script on sources of information and schooling situation, also adapted ${ }^{(7)}$, with eight questions for characterization of the students' schooling situation; Block III: Script on personal interest and prior contact of the student with the matter under study, with 11 questions elaborated by the researcher and by three nurses who teach at graduate nursing courses.

Data were collected in the morning or night, depending on the undergraduate course shift, in the classroom and at the beginning of the shift. Before data collection, the researcher contacted the head of the course and this helped him to locate the classroom and introduced him to the teacher in charge of the class. Subsequently, the researcher introduced himself to the teacher and to the students and explained the objectives, methodology and importance of the research.

Informed consent forms were distributed and read to students, and the students were told they had a period of 30 minutes to fill out the research instrument, which in the end varied from 26 to 31 minutes. The questionnaires and the consent form were put in separate envelopes to be delivered.

The collected data were entered in a previously prepared electronic worksheet in the Microsoft Excel $2007 \AA$ software, and they were later analyzed through descriptive statistics in the Epi Info 6.04® software.

The study complied with the formal requirements of national and international standards for research involving human subjects.

\section{Results}

Among the 107 students who answered the research instrument, 31 (29.0\%) attended the last semester of the undergraduate Nursing course at institution A, $17(16.0 \%)$ at B, $20(19.0 \%)$ at C and 39 (36.0\%) at D.

The majority of respondents were female (90; 90.7\%), aged 20-24 (63.3\%), and 11 students reported age $\geq 30$ years. Regarding skin color and marital status, $63.3 \%$ self-reported to be white and there was predominance of unmarried individuals (82.2\%).

Most of the students (94.4\%) lived in the urban area of their municipalities and $70.1 \%$ lived in Maringá. The majority (63.8\%) had a monthly family income between three and seven minimum wages, which was $\mathrm{R} \$ 622.00$ in 2012, and 46.2\% had paid employments, with 4 to 6 working hours, in addition to the academic training.

As to the students' previous schooling situation, $50(46.7 \%)$ had completed their education in public schools, and the majority in the daytime shift (73; 68.2\%). Almost half of the students (52; 48.6\%) attended pre-university courses. Of these, $53.8 \%$ did so for a period equal to or less than six months. The current situation of the students indicated that $40.2 \%$ had failed to be approved in courses at some point during the graduate training, $91.6 \%$ of the students were in the regular series, and $55.1 \%$ of them were enrolled in four to six courses in the ongoing academic year.

Regarding the insertion of content on initial care for burned patients in the academic training of nursing students, 101 students (94.4\%) reported that content was addressed at some point in the course, but $81.6 \%$ considered the approach insufficient (Table 1). 
Table 1 - Insertion of content on initial care for burned patients in undergraduate Nursing training

\begin{tabular}{lcc}
\hline & \multicolumn{1}{c}{ Yes } & No \\
\cline { 2 - 3 } Question & $\mathbf{n}(\%)$ & $\mathbf{n}(\%)$ \\
\hline $\begin{array}{l}\text { The content was addressed during } \\
\text { undergraduate training }\end{array}$ & $101(94.4)$ & $6(5.6)$ \\
$\begin{array}{l}\text { The student considers the approach } \\
\text { provided sufficient }\end{array}$ & $19(18.4)$ & $84(81.6)$ \\
$\begin{array}{l}\text { The student performed initial care for } \\
\text { burned patients }\end{array}$ & $30(28.0)$ & $77(72.0)$ \\
$\begin{array}{l}\text { The student performed nursing care for } \\
\text { burned patients }\end{array}$ & $37(34.6)$ & $70(65.4)$ \\
$\begin{array}{l}\text { The student witnessed the provision of } \\
\text { care for burned patients }\end{array}$ & $51(47.7)$ & $56(52.3)$ \\
$\begin{array}{l}\text { The student participated in theoretical } \\
\text { activities on the subject }\end{array}$ & $51(47.7)$ & $56(52.3)$ \\
\hline
\end{tabular}

A total of 30 (28.0\%) students reported practical experience in providing care for burned patients; the percentage was higher for those who had also performed nursing care for burned patients at other moments, and for those who only witnessed the provision of care for these patients. Participation in complementary theoretical activities (extra class) involving this theme was reported by $47.7 \%$ of the students, as shown in Table 1.

In relation to practical activities during academic training, we observed that $35.5 \%$ of the students had already provided some form of care for burned patients, such as initial care or nursing care for burned patients. These students had performed this care during their mandatory curricular traineeship, mainly in nursing wards $(18.7 \%)$ and emergency rooms (17.8\%). Regarding extra class theoretical activities, $16.8 \%$ had participated in some scientific event (course, convention, symposium, etc.) on the theme in question, $6.5 \%$ had carried out academic projects involving the theme and $5.6 \%$ had addressed burns as the central theme in the end-of-course written work.
As seen in Table 2, all students investigated considered important to approach the content on initial care for burned patients during the undergraduate nursing training, and $38.7 \%$ considered this content extremely important for professional practice and none of the respondents considered it unimportant or little important. However, $41.1 \%$ reported having little or no affinity for the content.

Table 2 - Affinity and importance attributed to content on initial care for burned patients according to nursing students

\begin{tabular}{lc}
\hline Variables & $\mathbf{n}(\%)$ \\
\hline Importance of the content & $107(100.0)$ \\
Yes & \\
Degree of importance for professional practice* & $25(23.6)$ \\
Important & $40(37.7)$ \\
Very important & $41(38.7)$ \\
Extremely important & \\
Afinity with the subject & $7(6.5)$ \\
None & $37(34.6)$ \\
Little & $32(29.9)$ \\
Some & $31(29.0)$ \\
\hline Much &
\end{tabular}

\section{Discussion}

The design, the population investigated and the region in which the present study was conducted represent a limitation because the results refer to a single specific location, period and context of teaching. The cross-section can contribute to a memory bias in relation to the student's experience, since the affinity that students have with the subject investigated, as well as the importance they attribute to it, may have 
influenced them to recall or not activities developed during the undergraduate training.

Although performed with a local population, this study has implications for nursing teaching since it shows important gaps in the academic training of the investigated students with respect to the subject. In this way, reflections on new methodologies to improve the teaching/learning process in undergraduate training regarding new and complex subjects such as burns must be stimulated.

Regarding initial care for burns, early measures, which must be performed within the shortest time possible after the accident, besides promoting analgesia, significantly reduce the injury, the risk of death, sequelae and other consequences ${ }^{(2,8)}$.

Although almost all Nursing students reported that content on initial care for burns was addressed at some point in their training, more than $80.0 \%$ rated this approach as insufficient. Thus, it can be inferred that these professionals did not feel confident or able to act in the face of an emergency involving a burned patient.

In the United States, due to the shortage of nursing staff, health services have hired newly trained nurses to work in critical care areas. A study carried out in this country with urgency and emergency nurses showed that the information provided during the academic training of these professionals was insufficient to act in services intended to patients in serious conditions, such as those victims of burns. These professionals were also found to be unprepared to work in emergency units shortly after their academic training ${ }^{(9)}$.

Theoretical information and the articulation of knowledge, as guiding threads to direct health practices, are essential to Nursing professionals who act in urgency and emergency situations. Nursing assistance to victims of severe burns is extremely complex and demands comprehensive technical-scientific knowledge. It requires also ability to deal with the patient and family emotional aspects, which can contribute to the faster rehabilitation ${ }^{(4,10-11)}$.

In this context, it is worrisome that only $28.0 \%$ of the nursing students had had the opportunity to participate in practical experiences of initial attendance to burned patients. This percentage is slightly higher than the one of those who assisted burned patients at other moments and those who only witnessed the provision of some form of care for burn victims.

The implementation of clinical practices plays an important role in the integration of theoretical knowledge and practical skills of nursing students; these practices are essential for the creation of competent and capable professionals. However, this can be a difficult time for these students as they experience intense changes in their way of thinking and acting. Students are faced with different situations and feelings, which are often never experienced. Such transformations are part of the educational process and of the modern pedagogical practice in which learning to be, to do, to know and to live together represents the foundation of the training of competent professionals for the labor market ${ }^{(12)}$.

An alternative to ameliorate the lack of opportunity to perform practical activities during academic training, which is the case of the majority of students, is to implement simulations in specialized laboratories. These would reproduce the essential aspects of a real clinical scenario, allowing students to approach and carry out procedures before their insertion in health services. Besides the educational aspect, this type of methodology is also effective from the ethical-legal point of view, as it provides the student, still inexperienced, a safer learning environment. It also results in greater safety to patients that will receive care in clinical settings. Although its use is rare in Brazil, this methodology has been showing good results in countries such as South Korea, Sweden and the United States ${ }^{(13-15)}$. 
The need to expand the knowledge on burns possibly led almost half of the students to attend some complementary extra class theoretical activities involving this theme, especially participation in scientific events. The fact that the students seek other activities, usually extracurricular, reflects the concern to compensate for the gap left in the undergraduate training and the need to perfect their training.

A study carried out in Netherlands evaluated the knowledge of physicians and nurses on care for victims of severe burns and revealed deficits in the theoretical-practical knowledge. The study also pointed out that the professionals who had received training on this topic had a better theoretical knowledge of treatment protocols and reference criteria in relation to those who did not have training ${ }^{(16)}$.

In relation to practical activities developed by the students aimed at assisting victims of burns, the most important were those performed during the mandatory curricular traineeship in nursing wards and emergency rooms. Studies indicate that nurses who have traineeship in the critical care area have a better acceptance when inserted in these units. Thus, some hospitals in the United States put effort on creating nursing residency programs in intensive care, with a combination of didactic and clinical content, for newly graduated nurses, seeking to fill the gaps in the undergraduate training ${ }^{(9)}$.

Although all students agreed that it is important to address the initial care for burned patients during undergraduate training and the majority consider the content highly relevant to professional practice, about $40 \%$ of them reported to have little or no affinity with this area. The lack of affinity with initial care for burned patients is a reason of concern, as affinity with a given area is directly related to the quality of the assistance provided. However, the indicated lack of affinity may also reflect the students' insecurity to carry out such care, which is a consequence of gaps perceived during their academic training.
The acquisition of competences and skills necessary to assist the health of patients in critical conditions, such as those severely burned, is expected among nurses working in emergency units ${ }^{(17)}$. In Brazil, nurses are the principal professionals responsible for providing care for critical patients, as well as for performing procedures of greater technical complexity that require scientifically based knowledge and also the ability of fast decision-making. Based on this, these professionals are legally responsible for provision of nursing care for victims of serious burns and they must, therefore, receive proper academic training, with satisfactory theoretical-practical knowledge, skills and abilities to act in this area.

The results obtained in the present study contribute to the reflection on the teaching-learning process in higher education institutions. The poor knowledge of the participants of this study on initial care for burn victims shows the need of institutions to train nursing professionals, to rethink the teaching models used in undergraduate courses, in order to produce critical-reflexive professionals with satisfactory theoretical-practical knowledge. As a strategy to achieve these results, we suggested to insert realistic simulation practices in the training of health professionals; these simulations would allow the practice of fundamental skills that are often not experienced in curricular traineeships, besides offering an environment that admits mistakes and professional growth, without endangering the safety of the patient.

\section{Conclusion}

Nursing care for burned patients during undergraduate academic training is experienced in theoretical courses, but only superficially. Furthermore, clinical practice is not always possible. In this sense, the approach to initial care for burn victims was reported by a large part of the students investigated. However, most of them evaluated it as insufficient. Less 
than a third of them had the opportunity to perform the initial attendance to burn victims during the undergraduate training and less than half had participated in some complementary theoretical activity on this topic, with emphasis to participation in scientific events. Nursing care for burn victims took place mainly during the curricular traineeship, in nursing wards and emergency rooms.

All students participating in this study consider important to approach the content about the initial care for burned patients during the undergraduate training. The importance of skills in this health area for nursing professional practice was also recognized by the majority of students. In contrast, a significant percentage of students reported having little or no affinity with such content.

\section{Collaborations}

Meschial WC participated in the collection, organization and analysis of data, writing of the article and approval of the final version to be published. Oliveira MLF contributed with the project conception, writing and critical analysis of the intellectual content of the article and approval of the final version to be published.

\section{References}

1. Toth JC. The participation of emergency nurses in the development of the Basic Knowledge Assessment Tool (BKAT) for the adult emergency department, the ED-BKAT2. J Emerg Nurs. 2013; 39(3):238-44.

2. Wallace HJ, O'Neill TB, Wood FM, Edgar DW, Rea SM. Determinants of burn first aid knowledge: Cross-sectional study. Burns. 2013; 39(6):1162-9.

3. Peck MD. Epidemiology of burns throughout the world. Part I: distribution and risk factors. Burns. 2011; 37(7):1087-100.
4. Tay PH, Pinder R, Coulson S, Rawlins J. First impressions last... A survey of knowledge of first aid in burn-related injuries amongst hospital workers. Burns. 2013; 39(2):291-9.

5. Coulson SG, Tay PH, Pinder RM, Rawlins J. Perception and knowledge of appropriate first aid care in burn related injuries: Survey of English university students. Br J Surg. 2012; 99:64.

6. Meschial WC, Oliveira MLF. Initial care to burn victims: nursing students' knowledge - a crosssectional study. Online Braz J Nurs [Internet]. 2014 [cited 2016 Oct. 20]; 13(4):518-28. Available from: http://www.objnursing.uff.br/index.php/ nursing/article/view/4744

7. Santos SMS, Oliveira MLF. Knowledge about aids and drugs among undergraduate students in a higher education institution in the state of Paraná. Rev Latino-Am Enfermagem. 2009; 17(4):522-8.

8. Wu W, Shi K, Jin Z, Liu S, Cai D, Zhao J, et al. Nursing research on a first aid model of double personnel for major burn patients. Cell Biochem Biophys. 2015; 71(2):1035-41.

9. Glynn P, Silva S. Meeting the needs of new graduates in the emergency department:aqualitative study evaluating a new graduate internship program. J Emerg Nurs. 2013; 39(2):173-8.

10. Chu W, Hsu L. The process of acquiring practical knowledge by emergency nursing professionals in Taiwan: a phenomenological study. J Emerg Nurs. 2011; 37(2):126-31.

11. Morais Filho LA, Marinho CSR, Backes VMS, Martini JG. Continuing healthcare education: a strategy to connect teaching and services. Rev Rene. 2013; 15(5):1050-60.

12. Wallin K, Fridlund B, Thorén AB. Prehospital Emergency Nursing students' experiences of learning during prehospital clinical placements. Int Emerg Nurs. 2013; 21(3):197-203.

13. Shin H, Ma H, Park J, Ji ES, Kimc DH. The effect of simulation courseware on critical thinking in undergraduate nursing students: Multi-site prepost study. Nurse Educ Today. 2015; 35(4):53742. 
14. Nyström A, Pålsson $Y$, Hofsten A, Häggström E. Nursing students' experiences of being video-recorded during examination in a fictive emergency care situation. Int J Nurs Pract. 2014; 20(5):540-8.

15. Kaplan BG, Connor A, Ferranti EP, Holmes L, Spencer L. Use of an emergency preparedness disaster simulation with undergraduate nursing students. Public Health Nurs. 2012; 29(1):44-51.
16. Breederveld RS, Nieuwenhuis MK, Tuinebreijer WE, Aardenburg B. Effect of training in the Emergency Management of Severe Burns on the knowledge and performance of emergency care workers as measured by an online simulated burn incident. Burns. 2011; 37(2):282-7.

17. Whetzel E, Walker-Cillo G, Chan GK, Trivett J. Emergency nurse perceptions of individual and facility emergency preparedness. J Emerg Nurs. 2013; 39(1):46-52. 